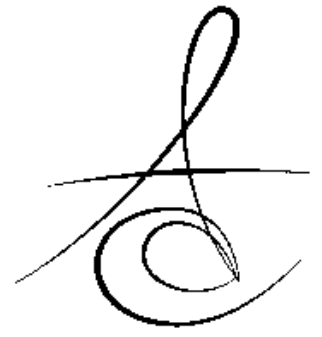

\title{
ADHESIVE PERFORMANCE OF A RESIN INFILTRANT ON PRIMARY TEETH DENTINE AFFECTED WITH AMELOGENESIS IMPERFECTA ${ }^{*}$
}

\section{REZIN INFILTRANTININ AMELOGENESIS IMPERFECTALI SÜT DIŞI DENTINI ÜZERINDEKI BAĞLANMA PERFORMASININ DEĞERLENDIRILMESI ${ }^{*}$}

\author{
Dr. Dt. Betül MEMIŞ ÖZGÜL* Prof. Dr. Firdevs TULGA ÖZ ${ }^{* *}$ \\ Dr. Dt. Murat CETINKAYA**
}

\begin{abstract}
Makale Kodu/Article code: 2605
Makale Gönderilme tarihi; 08.02.2016

Kabul Tarihi: 15.04.2016
\end{abstract}

\section{ABSTRACT}

Aim: In primary teeth with Amelogenesis Imperfecta (AI) dentine becomes hypermineralised following the loss of enamel which causes for bonding of teeth to get weaker. The purpose is to evaluate the effects of shear-bond strength of ICON material used in AI primary teeth.

Material and Methods: In the study 7 normal and 7 AI affected extracted primary teeth were used. Teeth were sectioned mezio-distally and 14 samples were created for each group. Then teeth were divided in to 2 subgroups of $n=7$. Group A: ICON (DMG,Germany) was applied to teeth then composite was applied as $1 \mathrm{~mm}$ increments. Group B: Teeth were treated with total-etch method then composite were applied as $1 \mathrm{~mm}$ increments. Shear-bond strengths of the samples were measured with Inströn.

Results: In AI primary teeth shear-bond strengths of Icon were found to be lower but not statistically $(p>0,05)$. However in normal primary teeth ICON materials shear bond strengths showed statistically lower values $(p<0,05)$.

Conclusions: The use of a resin infiltrant Icon to the HCAI affected dentin did not enhance the bond strength values however it might be beneficial if it's used as pre-treatment before application of a conventional adhesive. Further studies on the subject are needed on the subject.

Key Words: Amelogenesis imerfecta, Decidious teeth, dental bonding

\section{öz}

Amaç: Amelogenesis imperfectaya(AI) sahip süt dişlerinin hipoplastik minelerinin aşınarak kaybolmasıyla ortaya çıkan dentin dokusunun hipermineralize olması, bu dişlerin dolguyla bağlantılarını zayıflatmaktadır. Çaış̧mamızda yüzey tabakası hipermineralize olan başlangıç mine çürüklerine uygulanmak için geliştirilen Icon materyalinin, hipermineralize $\mathrm{AI}^{\prime}$ ı dentine bağlanma ajanı olarak uygulanmasının makaslama-bağ dayanımına etkisinin değerlendirilmesi amaçlanmıştır.

Gereç ve Yöntem: Çalışmamızda 7 'şer adet çekilmiş sağlam ve AI'ı süt azı dişi kullanıldı. Dişler meziodistal olarak ikiye ayrılarak her grup için 14 adet örnek elde edildi. Dişler Sağlam ve AI olarak ikiye ayrıldıktan sonra her ikiside $n=7$ olarak şekilde alt gruplara ayrıldı. Grup A: Dişlere ICON (DMG, Germany) materyali uygulandıktan sonra $1 \mathrm{mmlik}$ tabakalar halinde kompozit uygulandı. Grup B: Dişlere total etch yöntemi ile asit ve bonding işlemleri uygulandıktan sonra $1 \mathrm{mmlik}$ tabakalar halinde kompozit uygulandı. Elde edilen örneklerin makaslama bağ dayanımı değerleri Instron aletiyle ölçüldü.

Bulgular: AI'lı süt dişlerinde ICON uygulanmasının makaslama-bağ-dayanımı değerlerinin istatistiksel olarak anlamlı olmamakla beraber daha düşük olduğu gözlendi $(p>0,05)$. Sağlam süt dişlerinde ise makaslama-bağ-dayanımı değerleri ICON bonding ajan olarak uygulandığında istatistiksel olarak düşük bulunmuştur $(\mathrm{p}<0,05)$.

Sonuç: AI'ı dentinde ICON materyalinin bağlanma ajanı olarak kullanmasının makaslama-bağ-dayanımı değerlerini artırmamıştır, ancak geleneksel bonding ajanı öncesinde uygulanmasının faydalı olabileceği düşünülmektedir. Konu ile ilgili detaylı çalışmaların yapılması gerektiğini düşünmekteyiz.

Anahtar Kelimeler: Amelogenesis imperfecta, süt dişi, diş yapıştırma

*Baskent University Faculty of Dentistry Department of Paediatric Dentistry

${ }^{* *}$ Ankara University Faculty of Dentistry Department of Paediatric Dentistry

${ }^{* * *}$ Istanbul Special City Management Oral and Dental Disease Hospital,

₹ Bu çalışma 19. Türk Pedodonti Derneği Kongresi 04-07 Ekim 2012 Antalya'da poster sunumu olarak takdim edilmistir. 


\section{INTRODUCTION}

Amelogenesis imperfecta (AI) is a group of hereditary developmental disorder that affects the deposition, mineralization and maturation of the enamel of some or all teeth in the primary and/or permanent dentition ${ }^{1-3}$. The clinical appearance of enamel defects shows large variety, ranging from structure deficiencies to mineral and protein content defects ${ }^{1}$.

Clinical management of AI especially in young children is a complex set of treatments that usually aims to improve aesthetics and function of the teeth using bonded restorations ${ }^{2}$. In some cases the bonded restorations are successfully used however in many other patients, adhesive restorations show high failure rates ${ }^{4},{ }^{5}$.

Enamel of patients with hypocalcified amelogenesis imperfecta (HCAI) has a lower mineral content and thus is more porous and easily chips away, loss of enamel becomes apparent ${ }^{6}$.

Sanchez-Quevedo et al. ${ }^{7}$ showed that HCAI affected dentine responses to the enamel disorders by showing high calcium levels. HCAI affected dentine shows morphologic pattern that's similar to the sclerotic dentine in form of hypermineralization. Sclerotic dentine's high mineral content causes low bond values due the compromise in the formation of the hybrid layer ${ }^{8,9}$.

Saroglu et al. ${ }^{10}$ reported that deproteinization using sodium hypochlorite is an effective treatment in enhancing the enamel bonding in hypocalcified AI enamel, however no enhancing effect was seen on AI dentine.

Resin infiltration system Icon (DMG, Germany) was specially developed for removing the highly mineralized surface of initial caries lesions. Initial caries lesions are also known to have high mineral content, due to that it has been shown that adhesive penetration following two minutes of phosphoric acid application is superficial ${ }^{11,12}$. 60sec application of sodium hypochlorite thought to be promising method for deproteinization of initial caries lesions which is similar method that's used in AI as well ${ }^{13}$. Studies investigating a better penetration for initial caries lesions lead to the development of Icon (DMG, Germany) product which is a resin material that is applied following the $120 \mathrm{sec}$ Hydrochloric acid ( $\mathrm{HCl}$ ) etching and ethanol rinsing ${ }^{14}$. Studies showed that 120 $\mathrm{sec}$ application of $\mathrm{HCl}$ removes the high mineral concentrated layer of enamel lesions and hence enhances the resin penetration both in primary and permanent teeth ${ }^{12,15,16}$.

Since HCAI affected dentin is also highly mineralized like initial caries lesions, we hypothesize that resin infiltration system Icon would remove the mineralized surface layer and penetrate deeply in the HCAI affected dentine hence improve the shear bond strength values when used as a bonding agent.

The purpose of this study was to evaluate the effect of Icon resin infiltration material used as a bonding agent on dentin of the primary teeth affected with HCAI on the shear bond strength of adhesive system.

\section{MATERIAL AND METHOD}

\section{Specimen preparation:}

Seven primary molars were collected from boy and girl siblings aged 10 and 11 years, with HCAI. The diagnosis of HCAI was done by clinical examination and the criteria described by Witkop ${ }^{17}$. It has been noted that large areas of dentine with yellowish-brown discoloration was exposed and most of the enamel had been chipped away or worn off. Comparable seven non-carious teeth collected from apparently healthy 10-11 year old children served as control. The teeth used in this study were in time of exfoliation and collected after the patients' informed consent was obtained. The extracted teeth were stored in deionized water and were used within 1 month following extraction.

Normal and HCAI effect teeth were divided into two mesiodistally, following that the enamel layer of normal teeth were removed. A flat surface of $3 \mathrm{~mm}$ in diameter was prepared on the buccal and lingual dentin surfaces of all teeth by moist grinding on 200400 and 600-grit silicon carbide paper.

\section{Bonding procedures:}

The teeth with HCAI and the normal teeth were divided into two groups $(n=7)$ depending on the bonding type.

Group 1 (control group): Dentin surfaces of HCAI and sound primary teeth were etched for $20 \mathrm{sec}$ with 36\% phosphoric acid (Dentslpy, De Trey, York, $\mathrm{PA}, \mathrm{USA})$, then rinsed with water for $15 \mathrm{~s}$ and gently 
air dried for 1-2 s. A two-step etch-and-rinse

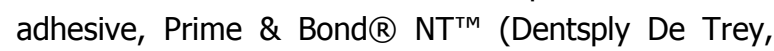
York, PA, USA), was applied to the dentine surfaces, air-dried, and light-cured for $40 \mathrm{~s}$ using a quartztungsten-halogen light-curing unit (Demetron LC, Kerr, Orange, CA, USA) operated at $600 \mathrm{~mW} / \mathrm{cm}$.

Group 2 (Icon group): Dentin surfaces of HCAI and sound primary teeth were etched for 120 s with $\% 10 \mathrm{HCl}$ (Icon etch, DMG, Hamburg, Germany), then rinsed with water for 30s and gently air dries for 1-2 s. Following that the teeth is rinsed with Icon Dry (Icon, DMG, Hamburg, Germany) for 30c and then gently air dried for 1-2 s. Icon resin (DMG, Hamburg, Germany) was applied for 3 minutes and light-cured for $40 \mathrm{~s}$ using a quartz-tungsten-halogen light-curing unit (Demetron LC, Kerr, Orange, CA, USA) operated at $600 \mathrm{~mW} / \mathrm{cm}$.

For both groups resin composite build-ups were performed on the bonded specimens using a light-cured microhybrid composite (Filtek Z250, 3M ESPE, St Paul, MN, USA) in five 1-mm increments that were light-activated separately.

Shear bond strength testing:

After storage in distilled water at $37{ }^{\circ} \mathrm{C}$ for 24 $\mathrm{h}$, Shear bond strength was measured in a Shear bond strength was measured in Instron Universal Testing Machine (Instron; Norwood, MA, USA). A parallel knife-edge shearing device was aligned $0.05 \mathrm{~mm}$ from the bonded interface and force was applied to failure

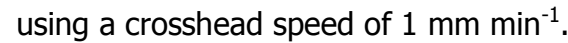

Statistical Analysis.

Sample size was calculated on the basis of data from a previous study ${ }^{10}$ on the shear bond strengths of HCAI with $a=0.05$ and $1-\beta=0.8$, we calculated that $n=7$ for each group would be needed to find significant differences. The data were analysed using Mann-Whitney $U$ test to evaluate differences among groups $(p<0.05)$.

\section{RESULTS}

The mean shear bond strengths for all groups are shown in Table 1.

Bond strength to HCAI dentin (15.6 MPa) and the normal teeth dentin (19.2 $\mathrm{MPa})$ showed no statistical difference $(p>0.05)$ in the control groups however bonding to the normal teeth showed numerical difference.
A statistically significant difference at $p<0.05$ level was detected when Icon was applied as a bonding agent between HCAI (12.8 MPa) and the sound primary teeth (16.1 MPa).

However, when the dentin shear bond strengths of the control and treatment groups were compared in normal teeth, significantly lower bond strengths were found in the Icon group $(P<0.05)$.

There was no statistical difference in the bond strengths of HCAI dentin between Icon group (12.8 $\mathrm{MPa})$ and control group (15.6 MPa) $(\mathrm{p}>0.05)$.

Table 1. Mean shear bond strengths of control and Icon treated dentin surfaces $(\mathrm{MPa})$

\begin{tabular}{c|cc}
$\begin{array}{c}\text { Treatment } \\
\text { groups }\end{array}$ & HCAI & $\begin{array}{c}\text { Sound Primary } \\
\text { Teeth }\end{array}$ \\
\hline \begin{tabular}{c|c} 
CONTROL \\
ICON
\end{tabular} & $15.6 \pm 3.8^{\mathrm{a}, \mathrm{A}}$ & $19.2 \pm 2.0^{\mathrm{b}, \mathrm{A}}$ \\
\hline & $12.8 \pm 1.4^{\mathrm{a}, \mathrm{B}}$ & $16.1 \pm 1.6^{\mathrm{c}, \mathrm{C}}$ \\
\hline
\end{tabular}

Groups identified by different lowercase superscript letters shows significant difference between columns and different uppercase superscript letters show significant difference between lines different at $P<0.05 . n=7$ in all groups.

\section{DISCUSSION}

Generally prosthetic restorations are preferred for adult population however ${ }^{18,19,20}$, it is not a good option for children due to ongoing growth so adhesive restorations are preferred. Minor defects of HCAI effected tooth can be successfully treated with adhesive restorations in children, however if most enamel is lost adhesive restorations are not as successful ${ }^{4,5,21}$. The reasons of failure are generally considered as the morphological and chemical differences between sound and AI teeth ${ }^{22,23}$.

There have been several methods investigated for enhancing the enamel and dentin bonding of HCAI teeth. Hiraishi et al. ${ }^{24}$ investigated the effect of extended etching time on the bond strength of $\mathrm{AI}$ effected teeth. Their results showed that bonding to the AI affected dentin could not be improved by extended etching time. Use of $\mathrm{NaOCl}$ has been shown to improve the bonding of HCAI enamel by several reports ${ }^{10,25,26}$. However, no improving effect of $\mathrm{NaOCl}$ has been observed when it's used in HCAI dentin ${ }^{10}$. Sanchez-Quevedo et al. $^{7}$ showed that HCAI affected 
dentine shows morphologic pattern similar to the sclerotic dentin which is characterized by thickening of the peritubular dentin and partial obliteration of the dentin tubules and hypermineralization. Tubule occlusion by mineral salts, preventing resin tag formation in sclerotic dentin is thought to be the reason why sclerotic dentin shows lower bond strength compared to the normal dentin ${ }^{9}$. This phenomenon is thought to be the explanation for the lower bond strengths in HCAI dentin compared to normal dentin ${ }^{10}$.

Bergman and Lind $^{27}$ reported that natural initial caries lesions are highly mineralized and shows mineral content of $83 \%$ in the surface layer. It has been shown that if the initial caries lesions are pretreated with phosphoric acid, adhesive penetration usually happens only superficially ${ }^{11}$. The low penetration values are explained by the highly mineralized surface layer of initial caries lesions, which inhibits the capillary penetration of the resin to deeper layers $^{11,12}$. It has been showed that $2 \mathrm{~min} \% 15 \mathrm{HCl}$ is more effective than 2 min $37 \% \mathrm{H}_{3} \mathrm{PO}_{4}$ in eroding the highly mineralized surface layer of enamel lesion both in primary and permanent teeth ${ }^{28,29}$. However the studies showed that even with the etching using $\% 15$ $\mathrm{HCl}$ for 2 min commercially available adhesives shows superficial penetration ${ }^{11,12}$. Thus a new low viscosity light curing material called as infiltrant is developed and manufactured with $15 \% \mathrm{HCl}$ etch as resin infiltrant Icon (DMG, Germany) system ${ }^{14}$. Studies showed that $3 \mathrm{~min}$ application of the infiltrant flowing 2 min etch with $15 \% \mathrm{HCl}$ penetrates better in the highly mineralized surface layer of initial caries lesions both in primary and permanent teeth ${ }^{25,26}$.

In the study we investigated if the use of Icon infiltrant could improve the adhesion of resin composite to HCAI affected dentin. Results showed that bonding with Icon did not had an enhancing effect furthermore the bond strength values with Icon bonding were lower compared to standard bonding procedures. Wiegand et al. $^{30}$ used the Icon as a bonding agent alone and as a pre-treatment before $35 \%$ phosphoric acid followed by a conventional adhesive, their results showed that the combination of resin infiltrant and conventional adhesive showed significantly higher shear bond strength values than the conventional adhesive alone however the Icon application alone didn't show any difference from the other groups in initial caries lesions. Chay et al. ${ }^{31}$ investigate the effect of Icon used as a bonding agent in hypomineralised teeth which are also known for low bonding strengths values. Their results showed that the use of resin infiltration alone as bonding decreased micro shear bonding values and also resulted in significantly lower micro shear bonding compared to normal enamel this results are in-line with our study ${ }^{31}$. Although our study investigated the effect in HCAI teeth, the results showed that the bonding strength decreased when Icon was used as bonding in HCAI teeth dentin and shear bond strength of normal teeth were greater compared to HCAI when resin infiltrant Icon is used as a bonding agent.

Shear bond strength values of $17-24 \mathrm{MPa}$ is generally accepted as the required value for composite resin to resist polymerization contraction forces ${ }^{32,33}$. Although Icon applied normal teeth showed higher values than HCAI affected teeth, our results showed lower values than $17 \mathrm{MPa}$ for all Icon applied groups. Also the bond strength values for both groups in HCAI affected dentin showed lower values than $17 \mathrm{MPa}$. Costenoble et al. ${ }^{34}$ investigated the effect of Icon pretreatment before orthodontic bracket bonding for eroded teeth and showed that resin infiltration for eroded teeth showed no significant differences in bond strength values compared to sound teeth. However their study also showed that if bonding was delayed following the pre-treatment the bonding values were lower for Icon application where the bonding strength value was also slightly lower than of $17 \mathrm{MPa}$ (16.6 MPa).

Our hypothesis that application of resin infiltration system as a bonding system for HCAI affected dentin would enhance the bonding values was rejected. At present it's still unclear which method would increase the shear bond strength values of HCAI affected dentin. It would be useful to investigate further effects of resin infiltration use combined with conventional adhesives and $\mathrm{NaOCl}$.

\section{CONCLUSION}

The use of a resin infiltrant Icon to the HCAI affected dentin did not enhance the bond strength values however it might be beneficial if it's used as pre-treatment before application of a conventional adhesive. Further studies on the subject are needed to 
find methods to enhance bonding to these morphologically altered tooth structures.

\section{REFERENCES}

1. Faria-e-Silva AL, De Moraes RR, Menezes Mde $S$, Capanema RR, De Moura AS, Martelli $\mathrm{H}$ Jr. Hardness and microshear bond strength to enamel and dentin of permanent teeth with hypocalcified amelogenesis imperfecta. 2011;21: 314-20.

2. MacDougall M, Simmons D, Gu TT et al. Cloning, characterization and immunolocalization of human ameloblastin. Eur J Oral Sci 2000; 108:303-10.

3. Bailleul-Forestier I, Molla M, Verloes A, Berdal A. The genetic basis of inherited anomalies of the teeth. Part 1: clinical and molecular aspects of non- syndromic dental disorders. Eur J Med Genet 2008; 51: 273-91.

4. Sabatini C, Guzmán-Armstrong S. A conservative treatment for amelogenesis imperfecta with direct resin composite restorations: a case report. J Esthet Restor Dent 2009; 21:161-9.

5. Pugach MK, Ozer F, Li Y, Sheth K, Beasley R, Resnick A, Daneshmehr L, Kulkarni AB, Bartlett JD, Gibson CW, Lindemeyer RG. The use of mouse models to investigate shear bond strength in amelogenesis imperfecta. J Dent Res. 2011;90: 1352-7.

6. Wright JT, Duggal MS, Robinson $\mathrm{C}$ et al. The mineral composition and enamel ultrastructure of hypocalcified amelogenesis imperfecta. J Craniofac Genet Dev Biol 1993;13:117-26.

7. Sanchez-Quevedo MC, Ceballos G, Garcia JM, Luna JD, Rodriguez IA, Campos A. Dentine structure and mineralization in hypocalcified amelogenesis imperfecta: a quantitative X-ray histochemical study. Oral Dis 2004;10:94-8.

8. Kwong SM, Tay FR, Yip HK, Kei LH, Pashley DH. An ultrastructural study of the application of dentine adhesives to acid-conditioned sclerotic dentin. J Dent 2000;28:515-28.

9. Tay FR, Pashley DH. Resin bonding to cervical sclerotic dentin: a review. J Dent 2004;32:173-96.

10. Saroglu I, Aras S, Oztas D. Effect of deproteinization on composite bond strength in hypocalcified amelogenesis imperfecta. Oral Dis 2006;12:305-8.
11. Paris S, Meyer-Lueckel H, Kielbassa AM. Resin infiltration of natural caries lesions. J Dent Res 2007;86:662-6.

12. Paris S, Meyer-Lueckel $H$, Cölfen $H$, Kielbassa AM. Resin infiltration of artificial enamel caries lesions with experimental light curing resins. Dent Mater J 2007;26:582-8.

13. Espinosa R, Valencia R, Uribe M, Ceja I, Saadia M. Enamel deproteinization and its effect on acid etching: an in vitro study. J Clin Pediatr Dent 2008;33:13-9.

14. Kugel G, Arsenault P, Papas A. Treatment modalities for caries management, including a new resin infiltration system. Compend Contin Educ Dent 2009;30:Spec3:1-10.

15. Meyer-Lueckel H, Paris S, Kielbassa AM. Surface layer erosion of natural caries lesions with phosphoric and hydrochloric acid gels in preparation for resin infiltration. Caries Res 2007;41:223-30.

16. Paris S, Dorfer CE, Meyer-Lueckel H. Surface conditioning of natural enamel caries lesions in deciduous teeth in preparation for resin infiltration. J Dent 2010;38:65-71.

17. Witkop CJ. Amelogenesis imperfecta, dentinogenesis imperfecta and dentin dysplasia revisited, problems in classification. J Oral Pathol 1989;17:547-53.

18. Köroglu A, Ekren O, Kurtoğlu C. Prostethic rehabilitation of patients with different types of amelogenesis imperfecta : Two case reports. Atatürk Üni Diş Hek Derg. 2012; Supplement-5 : 34-39.

19. Dikicier S. Prosthetic rehabilitation in a patient with amelogenesis imperfecta: A case report Atatürk Üni Diş Hek Derg 2014; Supplement: 9: 38-42.

20. Kirmali O, Sekmen T, Battal T. Aesthetics and Functional Rehabilitation of Amelogenesis Imperfecta: 4-Year Follow Up. Atatürk Üni Diş Hek Derg 2015; Supplement: 12: 61-65.

21. Vitkov L, Hannig M, Krautgartner W-D. Restortive therapy of $\mathrm{pr}$,mary teeth severely affected by amelogenesis imperfecta. Quintessence Int. 2006;37:219-24.

22. Seow WK. Clinical diagnosis and management strategies of amelogenesis imperfecta variants. Pediatr Dent 1993;15:384-93.

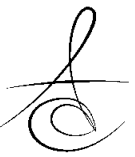


23. Seow WK, Amaratunge FA. The effect of acid etching on enamel from different clinical variants of amelogenesis imperfecta: an SEM study. Pediatr Dent 1998;20:37-42.

24. Hiraishi N, Yiu CK, King NM. Effect of acid etching time on bond strength of an etch-and-rinse adhesive to primary tooth dentine affected by amelogenesis imperfecta. Int J Paediatr Dent 2008;18:224-30.

25. Venezie RD, Vadiakas G, Christensen JR et al. Enamel pretreatment with sodium hypochlorite to enhance bonding in hypocalcified amelogenesis imperfecta: case report and SEM analysis. Pediatr Dent 1994;16:433-6.

26. Sönmez IS, Aras S, Tunc ES, Kücükesmen C. Clinical success of deproteinization in hypocalcified amelogenesis imperfecta. Quintessence Int. 2009; 40:113-118.

27. Bergman G, Lind PO. A quantitative microradiographic study of incipient enamel caries. J Dent Res 1966;45:1477-84.

28. Meyer-Lueckel $H$, Chatzidakis A, Naumann M, Dörfer $C E$, Paris $S$. Influence of application time on penetration of an infiltrant into natural enamel caries. J Dent. 2011;39:465-9.

29. Paris S, Soviero VM, Seddig S, Meyer-Lueckel H. Penetration depths of an infiltrant into proximal caries lesions in primary molars after different application times in vitro. Int J Paediatr Dent 2012;22:349-55.

30. Wiegand A, Stawarczyk B, Kolakovic M, Hämmerle $\mathrm{CH}$, Attin T, Schmidlin PR. Adhesive performance of a caries infiltrant on sound and demineralised enamel. J Dent. 2011;39:117-21.

31. Chay PL, Manton DJ, Palamara JE. The effect of resin infiltration and oxidative pre-treatment on microshear bond strength of resin composite to hypomineralised enamel. Int J Paediatr Dent. 2014;4:252-67

32. Barkmeier WW, Shaffer SE, Gwinnett AJ. Effects of 15 vs 60 second enamel acid conditioning on adhesion and morphology. Oper Dent 1986;11:111-6.

33. Swift EJ, Perdigao J, Heymann HO. Bonding to enamel and dentin: a brief history and state of the art. Quintessence Int 1995;26:95-110.
34. Costenoble A, Vennat E, Attal JP, Dursun E. Bond strength and interfacial morphology of orthodontic brackets bonded to eroded enamel treated with calcium silicate-sodium phosphate salts or resin infiltration. Angle Orthod. 2016 Mar 21. [Epub ahead of print]

\section{Yazışma Adresi:}

Betül MEMİS OZGUL

Baskent University Faculty of Dentistry, Department of Paediatric Dentistry, Ankara, TURKEY

e-mail: dtbetulmemis@hotmail.com 